\title{
Reviewer's comment concerning "Lumbar total disc replacement: predictors for 8-year outcome" (by H. Furunes et al. [2017] Eur Spine J)
}

\author{
Michael Mayer ${ }^{1}$
}

Received: 18 September 2017 / Accepted: 19 September 2017 / Published online: 23 November 2017

(c) Springer-Verlag GmbH Germany, part of Springer Nature 2017

This is a nicely written study with a strong methodology and interesting conclusions, which seem to add new aspects for the indication process for total lumbar disc replacement.

Unfortunately the study is based on the assumption that total lumbar disc replacement is an alternative to conservative therapy.

The international consensus is, and always has been, that total disc replacement is meant as an alternative to spinal fusion in patients with mainly discogenic low back pain, in whom conservative treatment has failed.

To my knowledge there is not one paper published about total disc replacement, which would promote this type of surgery as an alternative to conservative treatment [Zigler JE, Delamarter RB (2012) Five-year results of the prospective, randomized, multicenter, Food and Drug Administration investigational device exemption study of the ProDiscL total disc replacement versus circumferential arthrodesis for the treatment of single-level degenerative disc disease. J Neurosurg Spine 17(6):493-501; Bertagnoli R, Kumar S (2002) Indications for full prosthetic disc arthroplasty: a correlation of clinical outcome against a variety of indications. Eur Spine J 11(Suppl 2):S131-6; Siepe CJ, Heider F, Wiechert K, Hitzl W, Ishak B, Mayer MH (2014) Mid- to long-term results of total lumbar disc replacement: a prospective analysis with 5- to 10-year follow-up. Spine J 14(8):1417-31; Heider FC, Mayer HM, Siepe CJ (2015) Lumbar disc replacement: update. J Neurosurg Sci 59(2):169-80].

It should be clear to the spine surgeons community around the world that if the patient is not a surgical candidate, there is no indication for disc replacement and in my opinion disc replacement in such cases is not at all justified from a medical and the ethical standpoint.

I am well aware that the main results of this RCT have been published already, but this does not change the fact that the objectives of this study are simply wrong.

\section{Compliance with ethical standards}

Conflict of interest The author declares that he has no conflict of interests.
Michael Mayer

MMayer@schoen-kliniken.de

1 Spine Center, Schön Klinik München Harlaching, Harlachinger Str. 51, 81547 Munich, Germany 